\title{
Understanding the molecular basis of plant growth promotional effect of Pseudomonas fluorescens on rice through protein profiling
} Saveetha Kandasamy*1, Karthiba Loganathan ${ }^{1}$, Raveendran Muthuraj2, Saravanakumar Duraisamy ${ }^{1}$, Suresh Seetharaman ${ }^{1}$, Raguchander Thiruvengadam ${ }^{1}$, Balasubramanian Ponnusamy ${ }^{2}$ and Samiyappan Ramasamy ${ }^{1}$

\begin{abstract}
Address: ${ }^{1}$ Centre for Plant Protection Studies, Tamil Nadu Agricultural University, Coimbatore, India and ${ }^{2}$ Centre for Plant Molecular Biology, Tamil Nadu Agricultural University, Coimbatore, India

Email: Saveetha Kandasamy* - savee_patho2003@yahoo.co.in; Karthiba Loganathan - karthiba_patho@yahoo.co.in; Raveendran Muthuraj - raveendrantnau@gmail.com; Saravanakumar Duraisamy - agrisara@rediffmail.com; Suresh Seetharaman - ssuresh@india.com; Raguchander Thiruvengadam - raguchander@gmail.com;

Balasubramanian Ponnusamy - Balasubramanian@hotmail.com; Samiyappan Ramasamy - rsamiyappan@hotmail.com

* Corresponding author
\end{abstract}

Published: 24 December 2009

Proteome Science 2009, 7:47 doi:10.1 I86/1477-5956-7-47

This article is available from: http://www.proteomesci.com/content/7///47

(C) 2009 Kandasamy et al; licensee BioMed Central Ltd.

This is an Open Access article distributed under the terms of the Creative Commons Attribution License (http://creativecommons.org/licenses/by/2.0), which permits unrestricted use, distribution, and reproduction in any medium, provided the original work is properly cited.
Received: 5 August 2009

Accepted: 24 December 2009

\begin{abstract}
Background: Plant Growth Promoting Rhizobacteria (PGPR), Pseudomonas fluorescens strain KHI was found to exhibit plant growth promotional activity in rice under both in-vitro and in-vivo conditions. But the mechanism underlying such promotional activity of $P$. fluorescens is not yet understood clearly. In this study, efforts were made to elucidate the molecular responses of rice plants to $P$. fluorescens treatment through protein profiling. Two-dimensional polyacrylamide gel electrophoresis strategy was adopted to identify the PGPR responsive proteins and the differentially expressed proteins were analyzed by mass spectrometry.
\end{abstract}

Results: Priming of $P$. fluorescens, 23 different proteins found to be differentially expressed in rice leaf sheaths and MS analysis revealed the differential expression of some important proteins namely putative p23 co-chaperone, Thioredoxin h- rice, Ribulose-bisphosphate carboxylase large chain precursor, Nucleotide diPhosphate kinase, Proteosome sub unit protein and putative glutathione S-transferase protein.

Conclusion: Functional analyses of the differential proteins were reported to be directly or indirectly involved in growth promotion in plants. Thus, this study confirms the primary role of PGPR strain $\mathrm{KH}-\mathrm{I}$ in rice plant growth promotion.

\section{Background}

PGPR has promotional effect on plant growth and developmental processes in two different ways viz., 1) indirectly by decreasing or preventing some of the deleterious effects of a phytopathogenic organism; 2) directly by pro- moting plant growth through facilitating the uptake of nutrients from the environment [1]. Effect of PGPR on plant growth processes include, increase in germination rates, root growth, leaf area, chlorophyll content, magnesium, nitrogen and protein content, hydraulic activity, tol- 
erance to drought and salt stress, shoot and root weights and delayed leaf senescence [2]. PGPR mediated plant growth enhancement was reported by many workers $[3,4$, $1,5,6,7 \& 8]$. Our previous reports also revealed the growth promotional activity of $P$. fluorescens in rice under laboratory, glass house and field conditions. However, there is no information available on the molecular basis of host plant - PGPR interaction in promoting plant growth.

Among the various molecular biological techniques available, high throughput whole genome gene expression tools viz., microarrays and proteomics will allow us to have improved knowledge on the gene(s) and pathways induced during host-PGPR interaction. 2D-PAGE strategy has been widely used in understanding stress responses as well as in understanding constitutive differences between developmental stages or genotypes. First it provides the broad overview of proteins produced by both the partners. Second it allows the detection of signal transduction pathways and post-translational modifications of proteins, which decides the function of the protein. Recently, Shoresh and Harman [9] characterized Trichoderma harzianum and maize interactive proteins and reported the metabolic pathways induced by T. harizianum .

The present proteomic study was being carried out to dissect the molecular events induced or affected during ricePseudomonas interactions. Efficacy of $P$. fluorescens strain $\mathrm{KH}-1$ in promoting plant growth in rice under glass house and field conditions was studied. The study demonstrated the promotional activity of $P$. fluorescens strain $\mathrm{KH}-1$ on rice plant growth and yield [10]. 2D-PAGE analysis of leaf sheaths collected from control and PGPR treated plants revealed the induction of few key proteins involved in key energy metabolism.

\section{Results}

Effect of $P$. fluorescens on growth parameters in rice

Rice seeds treated with different bacterial suspensions showed improvement in plant growth parameters over untreated seeds. Among six strains of fluorescent pseudomonads, $P$. fluorescens strain KH-1 significantly increased the vigor index of rice seedlings. The increase in mean root length $(25.30 \mathrm{~cm})$ and shoot length $(11.88$ $\mathrm{cm})$ was significantly higher in seedlings treated with $P$. fluorescens $\mathrm{KH}-1$ compared to untreated control (Fig 1). The maximum vigor index of 3718 was observed in rice seedlings treated with $\mathrm{KH}-1$ suspension and less vigor index of 1654 was recorded from untreated control. In addition, greater wet $(1025.2 \mathrm{mg})$ and dry $(806.4 \mathrm{mg})$ weight was recorded in $P$. fluorescens $\mathrm{KH}-1$ treated seedlings where as in untreated control only 490.6 and 249.4 mg of dry and wet weight was recorded (Table 1).

\section{2-D PAGE analysis}

Based on the previous literature in rice proteomics, we chosen 2-DE gel with $\mathrm{pH}$ 4-7 range and a 12\% linear polyacrylamide gel for our experiments. A total of twelve 2-DE gels were run to study the Rice-PGPR interactions, which includes three sub-replications, two treatments (PGPR treated and untreated) and two biological replications. Protein spots were reproducibly resolved in all 12 gels which results in similar protein spot locations across all the replications (Fig 2A and 2B). 2D-PAGE analysis of PGPR primed and non-primed rice leaf sheath protein revealed the differential expression of 23 protein spots which showed significant difference in their abundance between control and treated samples. Among the 23 proteins, sixteen were up-regulated and seven were down-regulated (Table 2). Most distinct six differential spots were sequenced and functionally characterized.

\section{Analysis of differentially expressed proteins}

Analysis of PMF data of six proteins derived by MS analysis using MASCOT search algorithm showed homology to the following proteins 1) Putative p23 co-chaperone, 2) Probable thioredoxin h-rice, 3) Ribulose-bisphosphate carboxylase (RuBisCo) large chain precursor - rice chloroplast, 4) Nucleotide Diphosphate kinase, 5) Proteasome sub unit protein and 6) Putative glutathione S-transferase. The protein sequences were submitted to SWISSPROT and

Table I: Effect of different Plant Growth promoting rhizobacterial strains of $P$. fluorescens on seedling growth parameters under invitro conditions.

\begin{tabular}{|c|c|c|c|c|c|c|}
\hline Name of the Isolate & $\begin{array}{l}\text { Root Length } \\
\text { Mean (cm) }\end{array}$ & $\begin{array}{l}\text { Shoot length } \\
\text { Mean }(\mathrm{cm})\end{array}$ & Germination \% & Vigour Index & $\begin{array}{l}\text { Wet weight } \\
\text { (mg) }\end{array}$ & $\begin{array}{c}\text { Dry weight } \\
\text { (mg) }\end{array}$ \\
\hline $\mathrm{KH}-\mathrm{I}$ & $25.30^{\mathrm{a}}$ & $11.88^{b}$ & 100 & $3718^{a}$ & $1025.2^{b}$ & $806.4^{a}$ \\
\hline $\mathrm{AH}-\mathrm{I}$ & $25.08 \mathrm{c}$ & $11.32^{\mathrm{e}}$ & 100 & $3640^{c}$ & $995.5^{d}$ & $793.6^{b}$ \\
\hline Pf-I & $25.04^{c}$ & $11.64 c$ & 100 & $3668^{b}$ & $1057.1^{\mathrm{a}}$ & $739.3^{d}$ \\
\hline Py- 15 & $24.14 \mathrm{e}$ & $11.40^{\mathrm{d}}$ & 99 & $3518^{\text {de }}$ & $977.9^{f}$ & $738.1^{\mathrm{e}}$ \\
\hline TDK-I & $25.14^{b}$ & $11.92^{\mathrm{a}}$ & 100 & $3706^{a b}$ & $1007.6^{c}$ & $806.4^{a}$ \\
\hline MDU-2 & $24.68^{d}$ & $11.26^{f}$ & 99 & $3558^{d}$ & $986.7 \mathrm{e}$ & $752.7 c$ \\
\hline Control & $17.02^{f}$ & 5.968 & 72 & $1654^{f}$ & $490.6^{f}$ & $249.4^{f}$ \\
\hline
\end{tabular}

Values are mean of two replications. Means in a column followed by same superscript letters are not significantly different according to Duncan's multiple range test at $P=0.05$. 

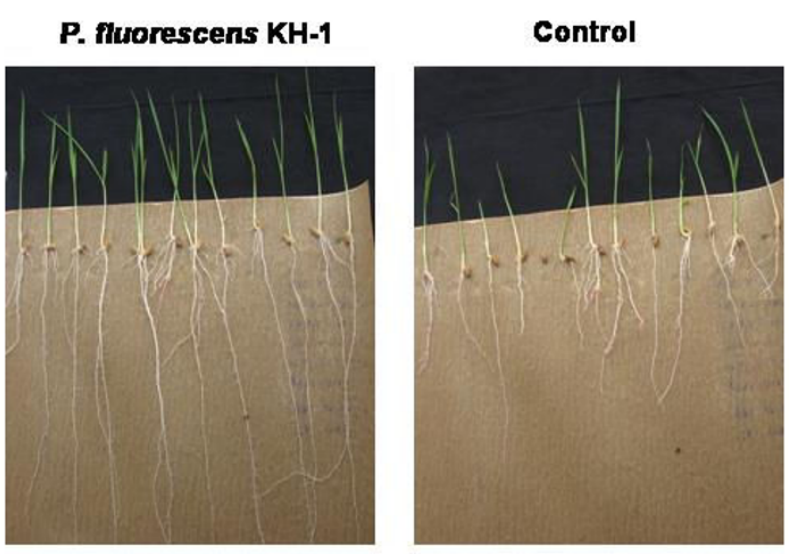

Figure I

Effect of $P$. fluorescens strain $\mathrm{KH}$ - I on rice growth parameters under in-vitro conditions. Rice seeds primed with PGPR and observations on root length and shoot length were recorded on $7^{\text {th }}$ day.

the accession No. were obtained from the Genbank organisation. The analysis showed that the protein spot 1 (Genbank accession no. P0C8Z0) has the role in energy metabolism where as protein 2 (Genbank accession no. A2YIW7) has functional role in defense and metabolism. Similarly, Protein spot 3 (Genbank accession no. P0C511), 4 (Genbank accession no. A6N0M9), 5 (Genbank accession no. P0C8Y9) and 6 (Genbank accession no. A1XBB7) have role in general metabolism, primary metabolism and defense, ISR, biotic and abiotic stress respectively (Table 3 ).

\section{Discussion}

Many rhizobacteria have been reported to stimulate plant growth under different conditions $[11,12,8]$. Seed treatment with fluorescent pseudomonads exhibited plant growth promotion in tomato and hotpepper [13]. In the present study, six PGPR strains were tested for their efficacy to promote plant growth under in vitro conditions. Among the various strains evaluated, $P$. fluorescens strains $\mathrm{KH}-1$ was found to be very effective in promoting seedlings growth in rice compared to other strains under in vitro conditions. In addition, the strain $\mathrm{KH}-1$ was effective in increasing yield and reducing pest and disease incidence on rice under different ecosystems [10]. 2D-PAGE analysis of leaf sheath proteome from control and treated plants showed the over expression of RuBisCO in P. fluorescens $\mathrm{KH}-1$ treated samples. It was reported that RuBisco plays a significant role in photosynthesis and accumulation of chlorophyll [14]. Thus, it is assumed that over expression of RuBisCO may lead to increase in the photosynthetic activity of treated plants in order to attain greater growth and possible link with plant defense.
Another PGPR responsive protein was found to be a chaperone which is known to be a stress-related protein that binds particularly to denatured proteins to prevent degradation and to assist in protein refolding of ATP [15]. In eubacteria and eukaryotic organelles, chaperonin 60 is presumably involved in numerous enzyme-folding functions [16]. In plant chloroplasts, the level of chapronin 60 , being involved in assembly of RuBisCO holoenzyme, is normally coordinate with RuBiSCO [17]. However, Holland et al. [18] reported that the accumulation of chapronin 60 in N. tabacum seedlings against salt, cold and prolonged darkness. This protein binds hsp90 and participates in the folding of a number of cell regulatory proteins. The amino-terminal domain ( $\mathrm{N}$-domain) of Hsp90 represents the ATP binding site and is important for interaction with its cochaperone, p23 [19]. The differential expression in our study indicates the involvement of co-chaperones in the assembly of RuBisCO which is an important enzyme in chloroplast metabolism and photosynthesis.

The priming of rice with $P$. fluorescens $\mathrm{KH}-1$ induced the over expression of Nucleoside diphosphate kinases (NDKs) which catalyze the exchange of phosphate groups between different nucleoside diphosphates [20]. NDK activities maintain equilibrium between the concentrations of different nucleoside triphosphates. The expression of plant NDPKs in response to wounding [21], heat shock [22], phytochrome B [23], UV-B light [24], oxidative stress [25] and hormones [26] has been reported by several research groups. These studies suggest that NDKs over expression in the current study might play regulatory roles in addition to their primary metabolic function.

Rice plants treated with strain KH-1 showed differential expression of proteosome sub unit alpha type-4-2 protein. The main function of the proteasome is to degrade unwanted or damaged proteins by proteolysis, a chemical reaction that breaks peptide bonds. These are known to be involved in the degradation of proteins modified by oxidation [27]. In mammalian cells, the proteasome sub-unit proteins have been shown to recognize and selectively degrade oxidatively damaged proteins, such as hydrogen peroxide-modified hemoglobin [28]. Amino acids of proteins can be modified by oxygen radicals or other activated oxygen that are produced as by-products of cellular metabolism or against abiotic and biotic stresses. Subsequently, oxidatively modified proteins can undergo chemical fragmentation or form aggregates due to covalent cross-linking reactions and increased surface hydrophobicity [29]. Thus, the expression of proteosome subunit proteins in the current study might involve in the cell metabolism, regulation of gene expression, and responses to oxidative stress as previously reported by Peters et al. [30]. 
Table 2: Differential proteome analysis of PGPR primed rice sheath tissues

\begin{tabular}{cccl}
\hline Spot ID & Molecular weight & Isoelectric focusing point $\mathbf{( p I )}$ & Change in rice protein profile due to PGPR priming \\
\hline 1 & 26 & 4.33 & Up regulated \\
2 & 08 & 5.16 & Up regulated \\
3 & 19 & 6.22 & Up regulated \\
4 & 07 & 6.30 & Up regulated \\
5 & 21 & 6.44 & Up regulated \\
6 & 31 & 5.35 & Up regulated \\
7 & 10 & 4.26 & Up regulated \\
8 & 27 & 4.24 & Up regulated \\
9 & 26 & 4.82 & Up regulated \\
10 & 28 & 4.75 & Up regulated \\
11 & 32 & 5.21 & Up regulated \\
12 & 32 & 5.45 & Up regulated \\
13 & 43 & 5.00 & Up regulated \\
14 & 66 & 5.45 & Up regulated \\
15 & 20 & 6.35 & Up regulated \\
16 & 27 & 6.81 & Down regulated \\
17 & 07 & 4.61 & Down regulated \\
18 & 44 & 4.89 & Down regulated \\
19 & 42 & 5.23 & Down regulated \\
20 & 19 & 5.74 & Down regulated \\
21 & 24 & 5.92 & Down regulated \\
22 & 10 & 5.67 & Down regulated \\
23 & 38 & 6.90 & \\
\end{tabular}

Similarly, the expression of GST is known to be involved in tagging toxic endogenous substrates with GSH conjugation to transport toxic substrates into the vacuole through a glutathione pump [31]. GST has numerous roles in cellular processes with a common function, namely the recognition and transport of a broad spectrum of reactive electrophilic compounds from both exogenous and endogenous origins [32]. Many plant GST genes were reported to be auxin inducible where GTS binds auxin at the noncatalytic site or catalytic site, depending on different auxins, suggesting that GTS plays different roles in auxin function. GST has an important role in plant defense from oxidative damages caused by various biotic or abiotc stresses such as heavy metal, wounding, ethylene, ozone, and pathogen attack [32]. From the known roles of GST, it is postulated that over expression of GSTs in this study might have an essential role in the ISR by priming rice plants and protecting cells from oxidative damage.

In addition, priming of rice plants with $P$. fluorescens $\mathrm{KH}-$ 1 induced the differential expression of thioredoxin proteins. The expression of Arabidopsis thioredoxin AtTRX3 in Saccharomyces strain EMY63 improved the methionine sulfoxide and $\mathrm{H}_{2} \mathrm{O}_{2}$ tolerance [33].

\section{Conclusion}

According to the previous reports, the presumed functions of the identified proteins are related to antifungal activity, energy metabolism, photosynthesis, protein degradation and antioxidation. This strongly implies the role of $P$. fluorescens $\mathrm{KH}-1$ in modulating various metabolic pathways including energy metabolism and plant defense. Further studies using detailed transcriptomics and proteomic analysis of rice-Pseudomonas interactions will allow us to manipulate the PGPR based crop health and yield response in rice through genetic engineering.

\section{Materials and methods \\ Effect of $P$. fluorescens on rice plant growth}

The fluorescent pseudomonad strains KH-1, Pf-1, TDK-1, MDU-2, PY-15 and AH-1 were grown separately in $100 \mathrm{ml}$ of King'B broth for $48 \mathrm{~h}$ on a rotary shaker (150 rev min$\left.{ }^{1}\right)$ at $28 \pm 2{ }^{\circ} \mathrm{C}$. The bacterial cells were harvested and centrifuged at $6,000 \mathrm{rpm}$ for $15 \mathrm{~min}$ and resuspended in phosphate buffer $(0.01 \mathrm{M}, \mathrm{pH}$ 7.0). Cell density was adjusted using a spectrophotometer to approximately $3 \times$ $10^{8} \mathrm{cfu} \mathrm{ml}^{-1}$ and used as bacterial inoculum. The bacterial suspension of Pseudomonas strains were prepared and tested for their plant growth-promoting activity in rice (var. Co43) using the standard roll towel method. Rice seeds soaked in $10 \mathrm{ml}$ of the bacterial suspension for $2 \mathrm{~h}$ were blot dried, placed in wet blotters and incubated in a growth chamber for 10 days. Seeds soaked in sterile water were used as controls. The vigour index was calculated using the following formula: vigour index $=$ percent germination $\times$ seedling length (shoot length + root length) 


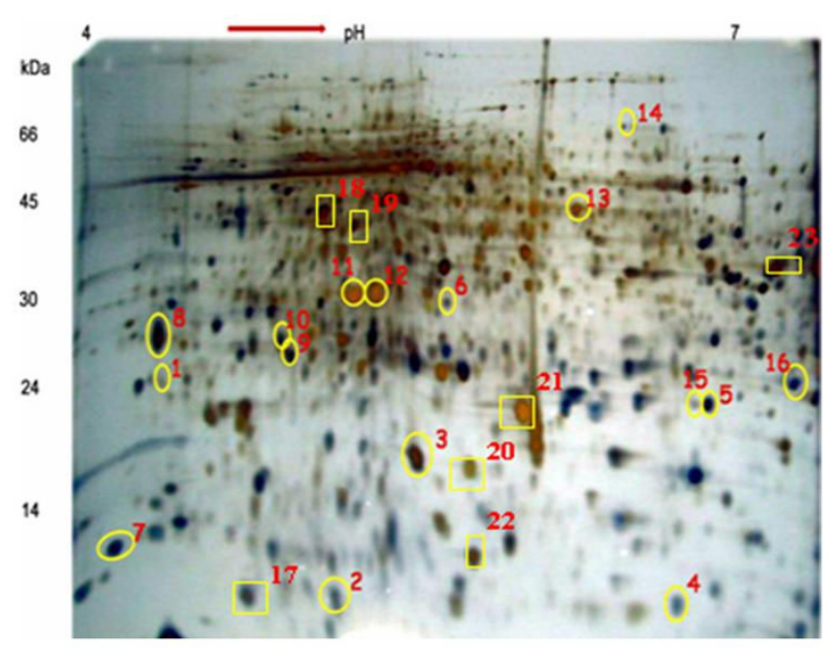

Figure 2

2-D gel analyses of proteins extracted from the leaf sheath tissues of rice plants primed with PGPR. In the first dimension (IEF), $100 \mu \mathrm{g}$ of protein was loaded on an 18 cm IPG strip with a linear gradient of $\mathrm{pH} 4-7$ and I2\% SDSPAGE gels were used in the second dimension. Proteins were visualized by silver staining. The circled spots represent the proteins that showed significant up-regulation upon PGPR priming and squares represent the significantly downregulated proteins during PGPR priming.

[34]. The experiments were repeated twice and each treatment had five replications.

\section{Preparation of talc based formulation of $\mathbf{P}$. fluorescens strain $\mathbf{K H}-\mathbf{I}$}

A loopful of $P$. fluorescens $\mathrm{KH}-1$ was inoculated into the King's B broth and incubated in a rotary shaker at $150 \mathrm{rpm}$ for $72 \mathrm{~h}$ at room temperature $\left(28 \pm 2{ }^{\circ} \mathrm{C}\right)$. After $72 \mathrm{~h}$ of incubation, the broth containing $9 \times 10^{8} \mathrm{cfu} \mathrm{ml}^{-1}$ was used for the preparation of talc-based formulation. To the 400 $\mathrm{ml}$ of bacterial suspension, $1 \mathrm{~kg}$ of the purified talc powder (sterilized at $105^{\circ} \mathrm{C}$ for $12 \mathrm{~h}$ ), calcium carbonate, $15 \mathrm{~g}$ (to adjust the $\mathrm{pH}$ to neutral) and $10 \mathrm{~g}$ carboxy methyl cellulose (CMC) (adhesive) were mixed under sterile conditions following the method described by Nandakumar et al. [35]. The product was shade dried to reduce the moisture content below 20 per cent and then packed in a polypropylene bag and sealed. At the time of application, the population of bacterium in talc formulation was checked to 2.5 to $3 \times 10^{8} \mathrm{cfu} / \mathrm{g}$.

\section{Treating rice plants with $\mathbf{P}$. fluorescens}

Paddy seeds (cv Co-43) were surface sterilized by $50 \%$ bleach and rinsed with water. The surface sterilized seeds were soaked in double the volume of sterile distilled water containing talc-based formulation (10 $\mathrm{g} \mathrm{kg}^{-1}$ of seed). After $24 \mathrm{~h}$, the suspension was drained off and the seeds were dried under shade for $30 \mathrm{~min}$ [35]. Treated seeds were kept for germination in Petri dishes at $28^{\circ} \mathrm{C}$ in the dark. Germinated seeds were placed in $16 \mathrm{~cm}$ diameter pots with required spacing. Thirty days after sowing, the seedlings were carefully transplanted to individual pots about 6 hills/pot ( 2 seedlings/hill). Before transplanting, seedlings were treated with PGPR by seedling dip method [the roots were dipped in water containing talc formulation $\left(20 \mathrm{~g} \mathrm{l}^{-1}\right)$ for $2 \mathrm{~h}$ ] without any mechanical damage. Twenty days after transplantation 5 gms of Talc based bioformulations was applied to each pot as soil application.

\section{Sampling}

Sampling of leaf sheaths was done from both control and treated plants at $48 \mathrm{~h}$ after soil application of $P$. fluorescens strain KH-1 and used for proteomic analysis. The experiment was repeated twice (biological replications) with adequate replications. From each biological replication, sampling of leaf sheaths was done (three replications) and protein extraction was done separately. After extraction, proteins isolated from respective treatments were combined and pooled protein sample was distributed equally into three aliquots which served as sub-replications of the pooled protein sample.

\section{D PAGE analysis}

\section{Protein extraction}

Frozen leaf sheaths were ground in a mortar using liquid nitrogen and suspended in 10\% trichloracetic acid (TCA) in acetone with $0.07 \%$ dithiothreitol (DTT) and kept at $20^{\circ} \mathrm{C}$ for $1 \mathrm{~h}$, followed by centrifugation for $15 \mathrm{~min}$ at $35,000 \mathrm{~g}$. The pellets were washed once with ice cold acetone containing $0.07 \%$ DTT at $-20^{\circ} \mathrm{C}$ for $1 \mathrm{~h}$ and centrifuged again for $15 \mathrm{~min}$ at $35,000 \mathrm{~g}$. This washing step was repeated four to five times until the supernatant was clear (free of chlorophyll). The final precipitated pellet was lyophilized for 2 hrs. About $10 \mathrm{mg}$ of the dried powder was used for protein extraction by dissolving in $350 \mu \mathrm{L}$ of sample lysis buffer containing $7 \mathrm{M}$ urea, $2 \mathrm{M}$ thiourea, 4\% 3- [(3-cholamidopropyl) dimethylammonio]-1-propanesulfonate (CHAPS), 0.5\% ampholytes (Bio-Rad) and $0.7 \%$ DTT. Protein extraction was done at $37^{\circ} \mathrm{C}$ with occasional vortexing. After $1 \mathrm{hr}$ incubation, cell debris were pelleted by centrifuging for $30 \mathrm{~min}$ at 35,000 $\mathrm{g}$ at room temperature. The supernatant was distributed in $100 \mu \mathrm{L}$ aliquots and kept at $-80^{\circ} \mathrm{C}$ before 2D-PAGE analysis [36]. The protein content was determined by Bradford method.

\section{D-PAGE}

Equal amount of protein $(100 \mu \mathrm{g})$ from control and treated samples were separated by 2D-PAGE. In the first dimension, IPG strips of $17 \mathrm{~cm}$ length and $\mathrm{pH}$ 4-7 were used. Electrophoresis was carried out at $500 \mathrm{~V}$ for $1 \mathrm{~h}$, followed by $1000 \mathrm{~V}$ for $1 \mathrm{~h}$ and 2950 for $24 \mathrm{~h}$. After IEF, the proteins were separated by SDS-PAGE in the second 
Table 3: List of expressed differential proteins in rice leaf sheath tissues in response to PGPR priming, identified through 2-DE-LC-MS/ MS

\begin{tabular}{|c|c|c|c|c|c|c|c|c|}
\hline Spot No & $\begin{array}{l}\text { Accession } \\
\text { number }\end{array}$ & Putative Function & Mass & pl value & Score & $\begin{array}{c}\text { Number of } \\
\text { peptides }\end{array}$ & Molecular function & $\begin{array}{c}\text { Functional } \\
\text { category }\end{array}$ \\
\hline 1 & $\underline{P 0 C 8 Z 0}$ & $\begin{array}{l}\text { Uncharacterized protein } \\
\text { Osl_027940 having higher } \\
\text { similarity with Putative } \\
\text { p23 co-chaperone }\end{array}$ & 22836 & 4.33 & 44 & 3 & $\begin{array}{c}\text { Assembly of RuBisCO } \\
\text { holoenzyme }\end{array}$ & $\begin{array}{c}\text { Energy } \\
\text { metabolism }\end{array}$ \\
\hline 2 & A2YIW7 & $\begin{array}{l}\text { Probable thioredoxin } \mathrm{h} \text { - } \\
\text { rice } \\
\text { (Phloem sap } 13 \mathrm{kDa} \\
\text { protein I) }\end{array}$ & 13319 & 5.16 & 140 & 10 & $\begin{array}{l}\text { Methionine sulfoxide and } \\
\mathrm{H}_{2} \mathrm{O}_{2} \text { tolerance } \\
\text { (Byproducts of oxygen } \\
\text { metabolism) }\end{array}$ & $\begin{array}{l}\text { Defense and } \\
\text { metabolism }\end{array}$ \\
\hline 3 & P0C5II & $\begin{array}{l}\text { Ribulose-bisphosphate } \\
\text { carboxylase large chain } \\
\text { precursor }\end{array}$ & 53418 & 6.22 & 95 & 8 & $\begin{array}{l}\text { Photosynthesis and } \\
\text { accumulation of } \\
\text { chlorophyll }\end{array}$ & Metabolism \\
\hline 4 & A6N0M9 & $\begin{array}{l}\text { Nucleotide DiPhosphate } \\
\text { kinase }\end{array}$ & 16835 & 6.30 & 118 & 6 & $\begin{array}{l}\text { Catalyze the exchange of } \\
\text { phosphate groups } \\
\text { between different } \\
\text { nucleoside diphosphates }\end{array}$ & $\begin{array}{l}\text { Primary } \\
\text { metabolism and } \\
\text { defense }\end{array}$ \\
\hline 5 & $\underline{\mathrm{POC} 8 Y 9}$ & $\begin{array}{l}\text { Proteosome sub unit alpha } \\
\text { type-4-2 protein }\end{array}$ & 27180 & 6.44 & 84 & 10 & $\begin{array}{l}\text { degradation of proteins } \\
\text { modified by oxidation }\end{array}$ & $\begin{array}{l}\text { Induced } \\
\text { systemic } \\
\text { resistance }\end{array}$ \\
\hline 6 & $\underline{\mathrm{A} I \mathrm{XBB7}}$ & $\begin{array}{l}\text { Protein IN2-I homolog B } \\
\text { (Putative glutathione S- } \\
\text { transferase GSTZ5) }\end{array}$ & 27458 & 5.35 & 71 & 4 & $\begin{array}{l}\text { Recognition and } \\
\text { transport of a broad } \\
\text { spectrum of reactive } \\
\text { electrophilic compounds }\end{array}$ & $\begin{array}{c}\text { Biotic and } \\
\text { abiotic stress }\end{array}$ \\
\hline
\end{tabular}

dimension using $12 \%$ polyacrylamide gels [37]. The gels were stained by silver staining method. For each biological replicate, one set of gels with high resolution running at different times were selected for further analysis. Relative abundance of protein spots was quantified with Melanie III (GeneBio, Geneva, Switzerland) after silver staining the gels and scanning with a densitometry (GS700, Bio-Rad).

\section{Protein identification}

Protein digestion

Differential protein spots were excised from preparative gels. The excised protein spots were digested with trypsin using the MassPREP station (Waters). The excised spots were de-stained with $50 \mu \mathrm{L}$ of $50 \mathrm{mM}$ ammonium bicarbonate and $50 \mu \mathrm{L}$ of $50 \%$ acetonitrile, washed once with $50 \mu \mathrm{L}$ of $100 \mathrm{mM}$ ammonium bicarbonate and $50 \mu \mathrm{L}$ of dehydrated acetonitrile. Digestion was done with $6 \mathrm{ng} \mu \mathrm{L}$ 1 trypsin in $25 \mu \mathrm{L}$ of $50 \mathrm{mM}$ ammonium bicarbonate for 5 $\mathrm{h}$ at $37^{\circ} \mathrm{C}$. The digested protein was extracted twice [first with $1 \%$ formic acid $(30 \mu \mathrm{L})$, and second with $1 \%$ formic acid $(12 \mu \mathrm{L}) / 50 \%$ acetonitrile $(12 \mu \mathrm{L})]$. The digested proteins were combined and maintained in a PCR plate at $4{ }^{\circ} \mathrm{C}$ for further analysis.

\section{Protein identification and sequencing by 2D Nano LC MSIMS}

Protein identification and sequencing was carried out using two dimensional liquid chromatography ESI MS (Agilent 1100 series 2DnanoLC MS). Tryptic digested pro- tein was subjected to column followed by reverse phase separation. Peptides get ionized in the liquid phase in the Electrospray ionizer and enter the ion trap, get fragmented (MS/MS) and detected. The data has been sent to MASCOT search engine (Agilent) for analysis.

\section{Database Searching with MSIMS Spectra}

MS/MS spectra were used to search against the NCBI nonredundant protein database using MS/MS Ion Search Engine, a computer software program conducting protein identification based on matching the MS/MS spectra of a protein with a protein or DNA sequence data base http:// www.matrixscience.com/search form select.html. The significance of the protein match with the ion score was based on the Mouse scoring algorithm [38]. The ion score was calculated as $-10 \times \operatorname{LOG} 10(\mathrm{P})$, where $\mathrm{P}$ is the absolute probability that the observed match is a random event. Thus, a relatively small $\mathrm{P}$ value means that the match of identified protein and the MS/MS spectra is not a random event. A significant specific match increases the ion core, so a high score means highly significant matching (MASCOT Help; http://www.matrixscience.com/help/ scoring_help.html). A single protein having a higher score than the minimum score for the significance level ( $\mathrm{p}<$ 0.05 ) was judged as a significant match. In each MASCOT search output result, the minimum score for significance level was provided, based on the absolute probability and the size of the sequence database being searched. 


\section{Competing interests}

More than five hundred PGPR strains have been isolated from various regions of India and their growth promotion and biocontrol ability has been tested in several crops by various research scholars of $\mathrm{Lab} \neq 20$, Department of Plant Pathology, Tamil Nadu Agricultural University, Coimbatore, India. Results have been published in various peer reviewed journal. This the first study on analyzing the molecular response of PGPR primed crop plant. This will be the base to progress further research at molecular level.

\section{Authors' contributions}

$\mathrm{KS}, \mathrm{MR}$ and RS have made significant contributions to design the objective and experiments. KS and LK were carried out the protein separation. KS and MR were potentially contributed the protein identification and interpretation of data. RS, TR and SS mobilized the necessary lab chemicals. PB provided facility. KS, DS, MR and RS have involved in drafting the manuscript or revising it critically for important content. All authors were significantly contributed and approved the final manuscript.

\section{Acknowledgements}

This is Scientific Paper from Centre for Plant Protection Studies and Centre for Plant Molecular Biology \& Biotechnology, Agricultural College and Research Institute, Tamil Nadu Agricultural University, Coimbatore-64I 003, Tamil Nadu, India. The research was supported by Ministry of Environment and Forestry (Government of India) and Department of Biotechnology (DBT), New Delhi, India.

\section{References}

I. Glick BR, Patten CL, Holguin G, Penrose DM: Biochemical and genetic mechanisms used by plant growth promoting bacteria. Imperial College Press, London Frankenberger WT; 1999:125-140.

2. Lucy M, Reed E, Glick BR: Applications of free living plant growth-promoting rhizobacterial. Antonie Van Leeuwenhoek 2004, 86(I): I-25.

3. Kloepper JW, Leong J, Teintze M, Schroth MN: Enhanced plant growth by siderophores produced by plant growth-promoting rhizobacteria. Nature 1980, 286:885-886.

4. van Peer R, Schippers B: Plant growth response in bacterization with selected Pseudomonas spp. strains and rhizosphere microbial development in hydroponic cultures. Can J Microbiol 1988, 35:456-463.

5. Hoffmann-Hergarten S, Gulati M, Sikora RA: Yield response and biological control of Meloidogyne incognita on lettuce and tomato with rhizobacteria. Z PflKrankh PfISchutz 1998, 105(4):349-358.

6. Kloepper JW, Lifshitz R, Schroth MN: Pseudomonas inoculants to benefit plant production. ISI Atlas Sci Anim Plant Sci 1988, 20:60-64.

7. Polyanskaya LM, Vedina OT, Lysak LV, Zvyagintev DG: The growthpromoting effect of Beijerinckia mobilis and Clostridium sp. cultures on some agricultural crops. Microbiol 2000, 71:109-115.

8. Saravanakumar D, Lavanya N, Muthumeena K, Raguchander T, Samiyappan R: Fluorescent pseudomonad mixtures mediate disease resistance in rice plants against sheath rot (Sarocladium oryzae) disease. Biocontrol 2009, 54(2):273-286.

9. Shoresh M, Harman GE: Genome-wide identification, expression and chromosomal location of the genes encoding chitinolytic enzymes in Zea mays. Mol Genet Genomics 2008, 147:2147-2163.

10. Saveetha K: Interactive genomics and proteomics of Plant Growth Promoting Rhizobacteria (PGPR) for the manage- ment of major pests and diseases in rice. In Ph.D. Thesis TNAU, Coimbatore-3, India; 2009:238.

II. Ramamoorthy V, Raguchander T, Samiyappan T: Induction of defense-related proteins in tomato roots treated with Pseudomonas fluorescens $\mathrm{PfI}$ and Fusarium oxysporum f.sp. lycopersici. Plant and Soil 2002, 239:55-68.

12. Saravanakumar D, Samiyappan R: ACC deaminase from Pseudomonas fluorescens mediated saline resistance in groundnut (Arachis hypogea) plants. J Appl Microbiol 2007, 102(5): 1283-1292.

13. Ramamoorthy V, Raguchander T, Samiyappan R: Enhancing resistance of tomato and hot pepper to Pythium diseases by seed treatment with fluorescent pseudomonads. Euro J Plant Pathol 2002, I08:429-44I.

14. Agrios GN: Plant Pathology. Department of Plant Pathology University of Florida, Elsevier Academic Press; 2005:635.

15. Rochester DE, Winer JA, Shah DM: The structure and expression of maize genes encoding the major heat shock protein hsp70. EMBO 1986, 5:45I-458.

16. Lorimer $\mathrm{GH}$ : Molecular chaperones as facilitators of protein folding. Invest Ophth Vis Sci 1996, 37: 1048-1048.

17. Avni A, Edelman M, Rachailovich I, Aviv D, Fluhr R: A point mutation in the glutathione peroxidase activity from Arabidopsis thaliana: molecular cloning and functional characterization. Eur J Biochem 1989, 21 6:579-858.

18. Holland N, Belkind A, Holland D, Dick U, Edelman M: Stressresponsive holoenzyme assembly in Nicotiana tabacum. EMBO 1998, 18:1915-1918.

19. Zhu , Tytgat J: Evolutionary epitopes of Hsp90 and p23:implications for their interaction. FASEB J 2004, 1 8:940-947.

20. Cho S, Shin S, Kim K, Kim Y, Eun M, Cho B: Enhanced Expression of a Gene Encoding a Nucleoside Diphosphate Kinase I (OsNDPKI) in Rice Plants upon Infection with Bacterial Pathogens. Mol Cells 2004, I 8(3):390-395.

21. Harris N, Taylor JE, Roberts JA: Isolation of a mRNA encoding a nucleoside diphosphate kinase from tomato that is up-regulated by wounding. Plant Mol Biol 1994, 25:739-742.

22. Moisyadi S, Dharmasiri S, Harrington HM, Lukas TJ: Characterization of a low molecular mass autohosphorylated protein in cultured sugarcane cells and its identifications as a nucleoside diphosphate kinase. Plant Physiol 1994, 104: I 40 I- I 409.

23. Choi G, Yi H, Lee J, Kwon YK, Soh MS, Shin B, Luka Z, Hahn TR, Song PS: Phytochrome signaling is mediated through nucleoside diphosphate kinase 2. Nature 1999, 401:610-613.

24. Zimmermann S, Baumann A, Jaekel K, Marbach I, Engelberg D, Frohnmeyer $\mathrm{H}$ : UV-responsive genes of Arabidopsis revealed by similarity to the Gcn4- mediated UV response in yeast. J Biol Chem 1999, 274: 17017-17024.

25. Moon H, Lee B, Choi G, Shin D, Prasad T, Lee O, Kwak SS, Kim DH, Nam J, Bahk J, Hong JC, Lee SY, Cho MJ, Lim CO, Yun DJ: NDPkinase 2 interacts with two oxidative stress-activated MAPKs to regulate cellular redox state and enhances multiple stress tolerance in transgenic plants. Proc Natl Acad Sci USA 2003, 100:358-63.

26. Novikova GV, Moshkov IE, Smith AR, Kulaeva ON, Hall MA: The effect of ethylene and cytokinin on guanosine 59-triphosphate binding and protein phosphorylation in leaves of Arabidopsis thaliana. Planta 1999, 208:239-246.

27. Grune T, Reinheckel T, Joshi M, Davies KJ: Proteolysis in cultured liver epithelialcells during oxidative stress. Role of the multicatalytic proteinase complex, proteasome. J Biol Chem 1995, 270:2344-235I.

28. Giulivi C, Pacifici RE, Davies KJA: Exposure of hydrophobic moieties promotesthe selective degradation of hydrogen peroxide-modified hemoglobin by the multicatalyticproteinase complex, proteasome. Arch Biochem Biophys 1994, 3 I I 3:29-34I.

29. Dean RT, Fu S, Stocker MJ: Davies Biochemistry and pathology of radical mediated protein oxidation. Biochem J 1997, 324: $1-18$.

30. Peters JM, Franke WW, Kleinschmidt JA: Distinct 19 S and 20 S subcomplexes of the $26 \mathrm{~S}$ proteasome and their distribution in the nucleus and the cytoplasm. I Biol Chem 1994, 269(10):7709-77।8.

31. Ishikawa T: The ATP-dependent glutathione S-conjugate export pump. Trends Biol Sci 1992, 17:463-68. 
32. Marrs TA: The functions and regulation of glutathione s-transferases in plants. Rev PI Physiol PI Molecul Biol 1996, 47: I-I 27.

33. Verdoucq L, Vignols F, Jacquot J, Chartier $Y$, Meyer $Y$ : In vivo characterization of a Thioredoxin $\mathrm{H}$ target protein defines a new peroxiredoxin family. J Biol Chem 1999, 274(28): 19714-19722.

34. Abdul-Baki AA, Anderson JD: Vigour determination in soybean seed by multiple criteria. Crop Sci 1973, 13:630-633.

35. Nandakumar R, Babu S, Viswanathan R, Raguchander T, Samiyappan $R$ : Induction of systemic resistance in rice against sheath blight disease by plant growth promoting rhizobacteria. Soil Biol Biochem 200I, 33:603-6I2.

36. Kim ST, Kim SG, Hwang DH, Kang SY, Kim HJ, Lee BH, Lee J], Kang $\mathrm{KY}$ : Proteomic analysis of pathogen-responsive proteins from rice leaves induced by rice blast fungus, Magnaporthe grisea. Proteomics 2004, 4:3569-3578.

37. Salekdeh GH, Siopongco J, Wade LJ, Ghareyazie B, Bennett : A proteomic approach to analyzing drought-and salt-responsive in rice. Field Crop Res 2002, 76:1999-2199.

38. Pappin DJ: Rapid identification of proteins by peptide-mass fingerprinting. Curr Biol 1993, 3(6):327-32.

Publish with Bio Med Central and every scientist can read your work free of charge

"BioMed Central will be the most significant development for disseminating the results of biomedical research in our lifetime. "

Sir Paul Nurse, Cancer Research UK

Your research papers will be:

- available free of charge to the entire biomedical community

- peer reviewed and published immediately upon acceptance

- cited in PubMed and archived on PubMed Central

- yours - you keep the copyright

Submit your manuscript here:

http://www.biomedcentral.com/info/publishing_adv.asp 